\title{
DiVINENESS REgARDING THE WORDS OF THE HOLY QUR'AN
}

\author{
Muhammad Sheibani \\ Faculty of Philosophy, Al-Mustafa International University, \\ Mashhad, I. R. Iran
}

\begin{abstract}
One of the many questions concerning the words of the Holy Qur'an is whether their content and meaning were truly a divine revelation or they were revealed to the Prophet from God and then transferred into the form of words. In this regard, there are two perspectives. First, as all Muslims believe, the words of the Qur'an are the result of a divine revelation, whereas the second viewpoint is that the words of the Qur'an are written by a human and not God. According to this latter perspective, the words of the Qur'an are sayings of the Prophet of which only the contents are based on a divine revelation.

The theory of the words of the Qur'an not being a divine revelation has been an abandoned and rejected one throughout the Islamic history. This is the reason it has not been the subject of any pertinent discussions. How can the words of the Qur'an be created by Muhammad or Gabriel even though it is believed that the Qur'an is a miracle? This article first defines the concept of revelation and then analyzes various viewpoints and opinions regarding this topic in order to conclude (with evidence) that the Qur'an is the word of God and not the word of the Prophet. If he had composed the words of the Qur'an and expressed the meaning of the revelation in his own words, then the Qur'an would not be the word of God. In this case, the term "word of God" indicates that the concept of the "word" should be considered. Thus, it is clear that the words of the Qur'an are divine and they can be referred and attributed to God.
\end{abstract}

Keywords: Revelation, Miracles, Words, Prophet Muhammad, Holy Qur'an

Corresponding author: sheibanimohamad@yahoo.com 


\section{Introduction}

Today, questions appear in journals concerning whether the words of the Holy Qur'an were based on a divine revelation. The question is raised whether the words of the Qur'an were from God just like the content and meanings, whether the Prophet Muhammad had no type of involvement in composing the words, or whether the text of the Qur'an was created by the Prophet or it was an inner experience of the Prophet who expressed it in his own words. This query has also been asked about the sacred texts of Christianity. However, there are two major differences between the motives and the purposes of the Bible and those of the Qur'an.

First, the question regarding the Holy Qur'an began centuries ago, as it is understood from the narrations in Al-itqan written by Suyooti and Al-Burhan, written by Zarkashi. This question and the creation of the opinion concerning the words of the Qur'an not being a divine revelation, was an issue initiated by the followers of the religion due to particular understandings of some verses or specific opinions about the "word of God," which will be discussed later in the paper. This question was introduced relatively late after the formation of Christianity and the reason this question was raised was due to some incompatibility between the Bible and scientific achievements. Before that time, there was a general consensus that the Bible's words were a divine revelation.

Secondly, even though the above question emerged somewhat late after Christianity was established, it received an immediate answer. After historical research about the Bible was developed, the fact was revealed that the text was written not by Moses or Jesus, but certain followers who were born after the life of these honourable prophets. In addition, the doubt that appeared about the words of the Bible being divine or not was changed into negativity and denial. However, in the case of the Qur'an, the opinions regarding the words of the Qur'an not being a divine revelation were seen as rare and unusual and over time, such opinions were rejected and eventually abandoned. Furthermore, scientific developments did not hinder the facts of the Qur'an, but instead, they helped approve its accuracy and authenticity. Accordingly, why has this rare idea been raised again? It is because some people are following the ideas of Western intellectuals who are attempting to bring the challenges and crises of Christianity into the Islamic world.

Therefore, this paper examines the issue regarding the words of the Holy Qur'an being a divine revelation, not from the perspective of it being an important topic, but from the viewpoint of certain attitudes toward religion and whether or not they are based on the opinion that the words of the Qur'an are not from a divine revelation. 


\section{The Concept of Revelation}

One of the major duties of the prophets is to receive the divine message, which is called the "revelation" (al-wahy). Speaking about the nature and the reality of a revelation is extremely difficult and unachievable since the revelation is not a natural phenomenon and it cannot be understood by scientific and standard tools. Instead, it is an extraordinary phenomenon between God and selected people (prophets) who can effectively judge the essence and reality of the revelation. However, its meaning and concept are reasonable and achievable. According to the sayings of the Prophets, it is possible to understand the concept of revelation through intellect, reasoning, and self-recognition:

a) Literal meaning: in the Dictionary of Lisan al-Arab, Ibn Manzoor writes that a revelation means giving signs, writings, letters, inspiration, hidden words, and anything that inspires others (Ibn Manzoor 1985: XV/240).

In his dictionary, Al-Mufradat, Raghib Isfahani writes that the root of revelation is a quick sign, which can include cryptic or figurative words as well as non-verbal sounds. This is the reason why anything that is done quickly is referred to as a "Wahy" revelation (Raghib Isfahani 2006: 515).

Linguists believe that the most comprehensive meaning of the word "revelation" is to make someone understand something both quickly and secretively so that it is understood by the person who is being addressed and not anyone else. This is the most common meaning, which is applicable to all meanings of the word, regardless of whether it is an existential command to an inanimate body, innate instincts of an animal, a natural understanding that comes to the heart of a normal person or the prophets' understanding of the divine law (Sharia) through a certain sign or hidden voice. In all these cases, understanding both quickly and secretively is of utmost importance (Mostafawi 2006: III/55).

b) Terminological meaning: in Islamic terminology, a revelation is a message of God that links the prophets to the unseen world and establishes a relationship with the supernatural. Since this type of messaging is both quick and hidden from others, it is called a "revelation" (Nasehiyan 2010: 41). Allama Tabatabai writes that a revelation includes divine words (immaterial) that some people - God willing - receive through a demonstration by God (Tabatabai 1992: 85). 


\section{The Concept of a Religious Experience}

An experience is an event that one goes through (either as a partaker or as an observer) and there are many types that comprise a wide range of categories including: artistic experiences, ethical experiences, pleasurable experiences, and sensory experiences. However, a religious experience differs from a common experience. In this particular experience, a person establishes a connection with the supernatural world or ultimate truth. For example, there is the manifestation of God in people, such as Jesus and the Virgin Mary, and situations in which one sees or talks to an angel (Peterson 2000:36-37).

In addition, one who undergoes a religious experience believes that describing the experience should not be based on natural phenomena (since it is incompatible and insufficient), but it should be explained through religious teachings. In other words, religious people give their experiences a religious interpretation and they describe their experiences according to religious teachings. Therefore, there are two conditions for an experience to be considered as religious. The first one is that it should occur within the boundaries of religion while the second is that the person who had such an experience should describe his/her state in relation to a religious concept (Sadeqi 2002: 132-134).

Accordingly, in terms of the subject of this paper, a religious experience is an experience created by the Prophet when he directly encounters God. In this confrontation, neither a message nor information is exchanged and transferred to the Prophet. As a result, the Prophet finds himself encountering a divine affair and what he conveys to the public as a revelation is not the word of God; it is simply an interpretation of his experience.

\section{The Difference between a Revelation and a Religious Experience}

There are fundamental differences between a revelation and a religious experience that reject the illusion that these two aspects are equal. This distinction is outlined as follows:

1. A revelation that descends from God to his messenger demonstrates that the Prophet possesses divine power. This is strong evidence for the invitation being from God (invitation to the faith) and for the revelation to be considered as divine. This extraordinary demonstration shown by the Prophet is referred to in the Holy Qur'an as Aya, which means a prophetic sign. Since this sign also reveals the incapability of others, Islamic theologians have called it a "miracle". Thus, the basic feature of a revelation is a miracle, which distinguishes itself from a religious experience. Based on these findings it is possible to see how a religious experience cannot be a miracle. 
2. Another point regarding the difference between a religious and a mystical experience is the experience of the individual who experiences it, which is influenced by his/her culture and belief. When a person is having a mystical experience, it is possible to view one's past and future. Hence the individual's belief and culture gives a particular identity to the overall experience.

However, a revelation of the Prophets is in contrast to a religious experience. In this regard, a revelation that a Prophet received went against the beliefs and ideas of his time, and it had the potential to completely change the prevailing circumstances. It was not only changes concerning the prevailing thoughts and opinions, but it was also changes in relation to ethical and social values. In fact, one of the qualities of the prophets is not being influenced by the environment and era that they live in, which is called "infallibility".

According to the religious scholar and philosopher Murtaza Mutahhari, their immunity meant that they were neither influenced by desire nor did they commit sins or make mistakes. Hence, their thoughts and actions are not influenced by the social habits and culture of their time. Consequently, after a revelation descends upon them from God, they convey it to the public without the slightest manipulation.

At this point, it is important to note the differences between prophets and geniuses. Geniuses are those with an exceptional talent in thinking, pondering, and calculating. Such individuals also focus on certain aspects based on their senses and they work on collected information according to their strong calculative ability, in addition to their sharp intellect, prophets are equipped with another power called a "revelation", which geniuses lack. Thus, based on this comparison, there are apparent differences between these two types of individuals.

3. The third difference between a revelation and a religious experience is that one of the necessities of a prophetic revelation must be leadership. Although the approach to so-called prophet-hood begins by first obtaining a nearness to God and becoming disconnected from people (which means centring only on inner experiences), the prophet eventually re-focuses his attention on outer experiences and guides the people toward a pleasant life (Mutahhari 1997: II/159-160). 


\section{Consequences of the Words of the Qur'an not Being a Divine Revelation}

Before examining the evidence, it is important to raise the following question: if we believe that words of the Holy Qur'an are not a revelation and they are simply made by a human, then what are the consequences? In order to answer this question, the following four points should be considered as the consequences of believing that the words of the Qur'an are not a divine revelation:

1. The first consequence is that it will remove the sanctity of the words of the Qur'an. Muslims have always valued the words of the Qur'an, and such respect can be seen in actions such as using calligraphy when writing the words of the Qur'an, developing the science of recitation and intonation when reciting the words of the Qur'an, and being clean when touching the words of the Qur'an. If we believe that the words of the Qur'an were created by a human, then this sanctity will vanish, and it will make the sacred words as common as those in ordinary books.

2. The second consequence is that we will have to deny the miraculous perspective of the words of the Qur'an. One of the miracles of the Qur'an, which was visible from the time of the Prophet, was the miracle of its expressiveness; that is, the rhetorical miracle of the Qur'an and its eloquence. Scientific miracle is another type of miracle in the Qur'an, which informed followers about scientific developments and human innovations that occurred as far as fourteen centuries earlier. However, the most important miracle of the Qur'an, which has been unanimously accepted by scholars from the beginning of the revelation until now, is the one of eloquence and expressiveness. There are different levels of this particular miracle such as beauty, rhythmic nature, incomparable preciseness, simplicity, order, and systematic selection. In this context, no human has the power to create sentences like those in the Qur'an. Conversely, if the words and phrases of the Qur'an are composed by humans, then it would show that other people can make phrases that are better or at least equal to those of the Qur'an, which would cause those to deny the miracle of such sacred words. Thus, it can be concluded that the miraculous text of the Qur'an is the best evidence for rejecting the opinion of the words of the Qur'an not being divine revelation.

3. The third consequence is the inherent danger of ignoring the sacred text completely, which would be detrimental to the future of the religion. 
4. The fourth and final consequence is the idea of religious pluralism. The infrastructure of religious pluralism is based on the concept that no religion is a complete carrier of the truth, but every religion carries a part of the truth. In other words, no single religion can have a monopoly over other faiths.

\section{Explaining the Different Viewpoints}

Before presenting and examining the different viewpoints, it is important to first define and analyze all of the possible assumptions. In this regard, the following five assumptions are defined:

1. The revelation that descended upon the Prophet included only meanings (not words) of the teachings of the Holy Qur'an. Consequently, the Prophet interpreted the meanings and conveyed them to the people (Tabatabai 1992: $\mathrm{XV} / 317)$. Allama Tabatabai mentioned this as one of the assumptions even though he did not believe in it.

2. The teachings of the Qur'an and the concept came from God, but the words were designed by archangel Jibraeel (Gabriel), who conveyed them to the Prophet (Zarkashi 2006: I/291). Zarkashi mentioned this assumption although he did not believe in it.

3. Only words, phrases, and sentences were first revealed to the Prophet, who then interpreted their meanings (Misbah Yazdi 2005: I/93). The author mentioned this viewpoint even though he did not believe in it.

4. Both the words and the meanings of the Qur'an composed by the Prophet are referred to God simply because God formed the meanings and the words (Tabatabai 1992: XV/317). Although he noted this assumption, he believed in the fifth assumption.

5. The meanings, words, terms, and phrases of the Qur'an are all from God. The Prophet Muhammad received and conveyed them to people without altering a single word and meaning.

After examining all five assumptions, it is apparent that some of them have not been accepted by the individual who initially made the assumption (al-mufassir).

According to Zarkashi, the following viewpoints are in accordance with three of the five aforementioned assumptions: 


\section{The First Viewpoint}

The meanings of the words and phrases in the Qur'an were first revealed by Allah, and then Gabriel and the Prophet Muhammad were the two intermediaries who conveyed the message of God to mankind (Assumption No. 5).

\section{The Second Viewpoint}

Only the meaning of the Qur'an was revealed by God through Gabriel and then the Prophet interpreted the meaning of the words and sentences, and demonstrated them to the believers (Assumption No. 1).

\section{The Third Viewpoint}

The meaning of the Qur'an was first taught to Gabriel, who then composed the words and conveyed them to the Prophet Muhammad (Assumption No. 2). (see: Zarkashi 2006: I/291)

Although Zarkashi did not name the adherents of each of the above-mentioned viewpoints, he showed that the Sunnis believed in the first viewpoint (ibid.).

Suyooti also quoted the first three viewpoints, and his emphasis on the first perspective provides some evidence (see: Suyooti 2001: I/58-59). It is also understood from the words of az-Zarqani that only three of the above viewpoints were accepted by the experts, and the last two assumptions (Assumptions No. 3 and No. 4) were not mentioned at all or they were simply not accepted among the religious scholars of the time (Zarqani 2006: I/41-41).

It is possible to obtain, from the words of Allama Tabatabai, that the fourth assumption (words and meanings were both from the Prophet Muhammad) had some supporters, although he considered this view as unreasonable and eventually rejected it (Tabatabai 1992: XV/317).

More unreasonable than the fourth assumption is the following perspective: the words and meanings of the Qur'an are both from the Prophet in which a level of his soul, called Rooh al-Ameen (Gabriel) induced the Qur'an to another level of his soul, which is referred to as Qalb (heart).

Among the different assumptions and perspectives regarding the words of the Qur'an, the following two perspectives are generally accepted by Muslim scholars and religious experts: 
A. Meanings and words of the Holy Qur'an are both from God

Since the early ages, the dominant view among Muslims was based on the principle that the Holy Qur'an, with all of its contents, was descended upon the Prophet Muhammad, who then delivered it to mankind as a mediator between the creator and the creature without the slightest change in a single word (see: Zarqani 2006: I/44; Zarkashi 2006: I/290; Ma'refat 1989). The efforts that the Prophet made in order to prevent any changes in the Qur'an is similar to asking a large number of believers to write and record the exact verses immediately after it was revealed, organize the team to educate $\mathrm{Mu}$ slims about the Qur'an, and emphasize reading and memorizing the sacred text. All of this suggests that the words, phrases, and combinations of the Qur'anic teachings originated from an infinite source of divine knowledge.

In addition, the practical conduct of Muslims when encountering the Qur'an demonstrates this fact. For example, Muslims have given the same level of importance to understanding the concepts of the Qur'an and they have attempted to stop the formation of any deviations in the words, sentences, modes of composition, structure of the eloquence, the appearance of the text, innovative style and rhythmic eloquence. Furthermore, the efforts of Muslim scholars concerning the appearance and verbal style of the Qur'an have been based on the belief that the words of the Qur'an are from God. Various issues concerning the manifestations of the Qur'an, such as the translation of the Qur'an into other languages, and the successive reliability of the Qur'an throughout the different periods of history also suggest that the Qur'an's content and its shape both originated from God. Finally, the belief that the words of the Qur'an are a divine revelation has been so deep among the faithful that the Qur'an and its unique and sacred text cannot be seen in any other light.

\section{Evidence of the first viewpoint}

Significant evidence has been presented for the words of the Qur'an being divine, which is shown in the following:

1. The Holy Qur'an introduced itself as the words of God:

If any of the idolaters ask you to give them refuge, give them asylum so that they may hear the words of God. (Qur'an 9:6)

In Surah Baqarah (Chapter 2) Verse 75 and Surah Fatah (Chapter 48) Verse 15 , the term "word of God" is mentioned. Attributing and referring a sentence 
to a certain speaker is logical and reasonable, as long as the speaker is responsible for the selection, compilation, and arrangement of the words in the composition of the sentence (Ma'refat 1989: I/210). However, if the mediator conveys the idea and the concept of the first person to the public, then the arrangement and combination of the words should be referred to the mediator and not the first person. Thus, referring to the words to the first person is unreasonable (ibid.: 44).

2. Without a doubt, one of the major parts of the miracle of the Qur'an is its apparent text structure, exquisite style, and unique manner. The incomparable eloquence of the Qur'an is a miracle unanimously accepted by Arabic language experts after they had seen the words and text of the Qur'an. In addition, the challenge and the inability of infidels to create sentences such as those in the Qur'an indicate that the verbal structure and the style of expression are from God. Thus, no human brain, even that of the Prophet Muhammad, could have been involved in the formation of the Qur'an's text (Zarqani 2006: I/44).

A. Many verses of the Holy Qur'an clearly indicate that its Arabic text is of divine origin. Some of these verses are as follows:

We have made it an Arabic reading text so that perhaps you may understand and verily, it is in the Mother of the Book, in Our Presence, high (in dignity), full of wisdom. (Qur'an 34: 3-4)

Before this (Qur'an), the Book of Moses was a guide and a blessing. This Book confirms the Torah. It is in the Arabic language so that it may warn the unjust people, and give glad news to the righteous ones. (Qur'an 46: 12)

In the first verse above, the sentence structure and Arabic language is explicitly attributed to God, and it is very clear that the "language" and "Arabic" has nothing to do with the content. Another verse from the Qur'an is proof of the lack of involvement by the Prophet in the structure of the text. The following are some examples:

Whenever Our authoritative revelations are recited to those who do not wish to meet Us in the life hereafter, say, "Bring us another book besides this one or change it." (Muhammad), tell them, "I cannot change it myself. I only follow what is revealed to me. I fear that for disobeying my Lord I shall be punished." (Qur'an 10:15) 
He does not speak out of his own desires. It is a revelation which has been revealed to him. (Qur'an 53: 3-4)

In addition to the above, other verses regarding recitation and how the Holy Qur'an was revealed to the Prophet include:

And recite what has been revealed to thee of the Book of thy Lord: none can change His words and none wilt thou find as a refuge other than Him. (Qur'an 18: 27)

The unbelievers have said, "Why was the whole Holy Qur'an not revealed to him at once?" We have revealed it to you in gradual steps to strengthen your hearts and give you explanations. (Qur'an 25: 32)

We shall be responsible for its collection and its recitation. When we recite it, we follow its recitation (by us). (Qur'an 75: 17-18)

We are about to reveal to you a mighty word. (Qur'an 73: 5)

It is obvious that the words "revelation" and "recitation" are related to the text and not to the content in any manner. After reading the above verses, there is no doubt that the words, verbal structure, and textual style as well as its content was revealed to the Prophet by means of the archangel Gabriel. Thus, the Prophet and Gabriel had only intermediary roles in receiving and delivering the divine revelation.

B. An explicit distinction between the text of the Qur'an and the sayings from the Prophet Muhammad is not hidden from any Arabic expert. This is another reason for the words of the Qur'an being divine. When Arabs living in the time of the Prophet first heard the verses of the Qur'an from him, they found that some words were far superior compared to other man-made phrases and thus, they admitted the sacredness of the words. Some of them immediately became believers whereas others admitted the beauty and sacredness of the Qur'an, but carried on with their hostility (Ma'refat 1989: IV/23-29).

Zarqani, who was aware of the delicacy of this evidence, wrote about this under the title Style of Hadith (Narration of Prophet) and the Style of the Quran (see: Zarqani 2006: II/235).

Arabs living in the time of the Prophet Muhammad knew of his speaking power even before the revelation of the Qur'an. Yet, none of the deniers of the Prophet suggested that the Qur'an were his words since there was a clear difference in the words of the Prophet and the words of the Qur'an: 
(Muhammad), tell them, "Had God wanted I would not have recited it (the Book) to you nor would I have told you anything about it. I lived among you for a whole life-time before it was revealed. Will you then not understand?" (Qur'an 10: 16)

C. The teachings, facts, and contents of the Qur'an are of such greatness, depth, and breadth that putting them into words and phrases demonstrates a power beyond human ability. As the Qur'an states regarding the magnitude and greatness of the revelation: "We are about to reveal to you a mighty word" (73: 5)

Conversely, the Prophet is introduced as a human like other people of his time, but with one major difference: the Prophet is used to receive the divine revelation:

Say, "I am only a mortal like you but I have received revelation that there is only one Lord." (18: 10)

Since the Prophet was pure and untarnished by impurities (see: Qur'an 33: 33), he was able to receive the divine revelation and convey the message to people without the slightest modifications. In addition, expressing the heavenly truths and profound content from God and shaping them into words exceeds the abilities of humankind and Jinn (see: Qur'an 17: 88). Jalaluddin Suyooti provides the same proof, too (2001: I/59).

Each word of the Qur'an includes many meanings that cannot be fully understood by just anyone. Thus, it is impossible to replace a single word of the Qur'an with a new one that includes all aspects of the sacred text (ibid.).

In sum, the above arguments show that the words, phrases, and sentence structure of the Qur'an are from God and through the angel Gabriel, the Prophet Muhammad conveyed the message to mankind without the slightest changes. The Qur'an is a blessing of God in which it has addressed all people equally throughout history.

B. The content of the Qur'an is from God and the words are from the Prophet

The second viewpoint is that only the divine content was revealed upon the Prophet Muhammad after which he composed the teachings in his own words. The root of this perspective comes from a known theologian of the third century, Ibn Kellab Abu Muhammad Abdullah ibn Sa'id Bin Al-Qattan Basari. A pioneer compiler of theology, he was followed by Hasan Al-Ash'ari, who founded a belief known as "Ash'ari theology". Ibn Kellab became one of 
the known opponents of the Mu'tazilah (Mutazelites) and compiled several books against them. The date of his death is not precisely known, but it has been written that he passed away after the year 240 in the lunar calendar. The theological beliefs and ideas of Ibn Kellab had a significant impact on the formation of Islamic theology. After his death, theologians either supported him or strongly opposed him in theological discussions. His followers were known as "Kelabya" (see: Musavi Bojnurdi 1991: IV).

Ibn Kellab was the leading theorist of the School of Asha'irah. He believed that the mortal word of God never descended into the world as a compiled book. Moreover, other than his views accepted by the Ash'ari, there are some ideas that he does not share with others about the Qur'an and other divine scriptures, which is seen in the following:

The interpretation of the words of the Qur'an in Arabic or Hebrew is not an exact wording of the Qur'an. According to his belief, after the revelation was heard by the Prophet, the phenomenon of interpretation occurred, which included Arabic characteristics. (Shabestari 1996: 126)

He believed that the limitations of the Arabic language caused the word of God to be limited and it gave the word of God a humanly characteristic. (ibid.)

The opinions of Ibn Kellab regarding the text of the Qur'an were highly criticized by renowned scholars, such as Qazi Abd al-Jabbar, and Abul Hasan Ash'ari in the fourth and fifth centuries as well as Ibn Taymiyyah in the sixth century (ibid.). However, throughout history, this idea has always been a rare viewpoint among scholars attempting to interpret the Qur'an. By stating this viewpoint beside the first one (the view of the majority of Muslims in the first centuries of Islam) in important sources, such as Al-Burhan by Zarkashi, Al-Itqan by Suyooti, and Manahil al-Irfan by Zarqani as well as the quotations of previous scholars, it indicates the continuous presence of this viewpoint in religious discussions even though none of these sources have accepted this perspective. Thus, it appears that the aforementioned viewpoint has been of more interest in the last century, since modern writers in the Islamic world, such as Dr. Nasr Hamid Abu Zayd (an Egyptian thinker), believe in this particular standpoint, either intentionally or unintentionally.

\section{Review and Analysis}

Supporters of the above viewpoint have only claimed their stance without providing proof or logical reasoning. Perhaps some verses of the Qur'an 
can serve as evidence and documentation for this perspective, especially where God states that he has revealed this Qur'an onto the heart. In this regard, it is obvious that a revelation on the heart does not need any words or phrases (Zarandi 1990: 45).

Let us examine the following verse:

It has been revealed through the trustworthy Spirit to your heart, so that you will warn (the people of the dangers of disobeying God).

(Qur'an 26: 193-194)

Based on the above verse from the Qur'an, the revelation occurred on the heart of the blessed Prophet Muhammad. In this case, inserting anything into the heart does not need verbal phrases to be applied; that is, verbal messages are conveyed through the ears and not the heart.

It seems that the five proofs mentioned above support the first viewpoint, but they can also easily reject the second viewpoint. Furthermore, using the above verses to prove the aforementioned viewpoint is controversial and flawed in the following ways:

\section{The First Point}

The verses used to support the first viewpoint clearly show the divine words of the Qur'an, the Arabic structure of the Qur'an, and the words "recitation" and "revelation", all of which are considered as characteristics of the text. The verses also show that the Prophet Muhammad "follows the divine revelation and does not interfere in changing the revelation". In some verses, the Arabic language of the Qur'an directly refers to God (as in Verses 3-4 of Surah Zukhruf and Verse No. 5 of Surah Yusuf). Therefore, the interpretation of the verses of the Qur'an in regard to how the sacred text was revealed on the heart of the Prophet must be compatible with the larger collection of verses.

\section{The Second Point}

The divineness of the words of the Qur'an is not in contrast to the revelation on the heart of the Prophet, because neither the Qur'an nor any of the scholars believe that the words of the Qur'an and the revelation are explainable through sensory and material mechanisms. Although the faithful believe that the Qur'an was revealed in divine words of the Arabic language from its inception, this does not mean that it should involve sensory organs, such as the mouth, tongue, and ears, for the sake of revelation. Since the 
divine revelation is based on intuitive knowledge (al-Ilm al-Huzoori), the apparent structure of the Qur'an can also be based on such knowledge (Misbah Yazdi 1988: 26-27). Therefore, this is how the Prophet conveyed the message to the people without making any modifications.

In addition, the verses of the Qur'an that mention the heart of the Prophet as the location of the revelation are not only in contrast to those verses that consider the text of the Qur'an to be divine, but they also show how both groups of verses complement one another. Furthermore, Allama Tabatabai, in his book explaining Verses 193-194 of Surah Shu'araa (how the Qur'an was revealed on the heart of the Prophet), rejects the viewpoint that attributes the text of the Qur'an to the Prophet. He believes that the word "heart" in this verse is the soul of the man that possesses sense, understanding, and willpower. He also clearly asserts that when the revelation was revealed on the Prophet, none of his external senses where involved. In other words, at the time of the revelation, the Prophet saw the angel and heard his voice without using his eyes, ears, and external senses (Tabatabai 1992: XV/317).

\section{The Third Point}

In Surah Shu'araa Verse 195, it is written, "It has been revealed in plain Arabic". This shows that the revelation on the heart of the Prophet is not in contrast with the divine text of the Qur'an. Therefore, the verses about the Qur'an being revealed on the heart of the Prophet cannot serve as proof for the second viewpoint.

\section{Conclusion}

First, the word "recitation", used for what has been revealed from God to the Prophet, shows that the words of the Qur'an are divine. Second, the phrase "word of God" has been used twice in the Qur'an to define the text, as seen in the following verses:

If any of the idolaters ask you to give them refuge, give them asylum so that they may hear the words of God. Then, return them to their towns for they are an ignorant people. (Qur'an 9:6)

They desire to change the word of Allah. (Qur'an 48: 15)

The meaning of the "word of God" in these verses is part of the Qur'an and it signifies the divineness of the sacred text. According to the Arabic dictionary, a "word" is an utterance that conveys a meaning. In this regard, 
words and meanings are derived from the concept of a "word". This is why Surah Tawba Verse 6 uses the verb "hear". Finally, a speaker's word can be true as long as he inserts meaning into the words and composes it himself. If the Prophet had composed the words of the Qur'an and placed meaning in them, then the Qur'an is not the word of God. However, the findings of this paper show that the "word of God" in the Qur'an and the concept of the "word" indicate that the words of the Qur'an are, in fact, Godly and divine.

Received: June 23th, 2014

Accepted: September 25th, 2014

\section{References}

Holy Qur'an.

Abu Zaid, Nasr Hamid (2000), Mafhoom al-Nass - Dirasatun fi Uloom al-Qur'an, al-Markaz al-Saqafi al-Arabi, $5^{\text {th }}$ edition, Beirut, Lebanon.

Halabi, Ali Asghar (1995), History of Contemporary Religious and Islamic Movements, Bahbahani, Tehran, Iran.

Ibn Manzoor, Muhammad ibn Mukram (1985), Dictionary of Lisan al-Arab, Adab Al-Hawzah, Qum, Iran.

Isfahani, Raghib (2006), Dictionary of Al-Mufradat fi Ghareeb al-Qur'an, Uroomiyah.

Khorramshahi, Baha al-din (1985), Hermeneutic and New Hermeneutics, Keyhan, Tehran, Iran.

Ma'refat, Muhammad Hadi (1989), At-Tamheed fi Uloom al-Qur'an, Markaze modiriyate al-Hawzah al-ilmiyya, Qum Iran.

Mir Muhammad Zarandi, Seyyed Abol-Fazl (1990), History and Qur'anic Sciences, $2^{\text {nd }}$ edition, Daftare Entesharate eslami, Qum, Iran.

Misbah Yazdi, Muhammad Taqi (1988), Recognition of Leader, Markaze modiriyate al-Hawzah al-ilmiyya, Qum Iran.

Misbah Yazdi, Muhammad Taqi (2005), Recognition of Holy Quran, Volume 1, Institute of Education and Learning "Imam Khomeini", Qum, Iran.

Mostafawi, Hasan (2006), At-Tahqeeq Fi Kalimat al-Qur'an, Ministry of Culture and Islamic Guidance, I. R. Iran.

Musavi Bojnurdi, Muhammad Kazim ibn Hasan (1991), Great Islamic Encyclopedia, Volume $4,1^{\text {st }}$ edition, Tehran.

Mutahhari, Murtaza (1997), Majmu'eye Asar, Volume 2, Sadra, Tehran.

Peterson, Michael (2000), Reason and Religious Belief, Translated by Ahmad Naraqi \& Ebraheem Soltani, Tarhe No, Tehran. 
Nasehiyan, Ali Asghar (2010), Quranic Sciences in School of Ahlulbayt, Islamic University "Razawi”, Mashad, Iran.

Sadeqi, Hadi (2002), New Theology, Ketabe Taha wa Nashre Eslami, Qum, Iran. Shabestari, Muhammad Mujtahid (1996), Hermeneutics of Quran and Sunna, Tarhe No, Tehran.

Suyooti, Jalal al-din Abd ar-Rahman (2001), Al-Itqan fi Uloom al-Qur'an, Fakhr ad-Din.

Tabatabai, Allama Muhamad Hussain (1982), Qur'an in Islam, Daftare Entesharate Eslami.

Tabatabai, Allama Muhammad Hussain (1992), Tafsir al-Mizan, Institute of Nashre Islami, Qum, Iran.

Zarkashi, Badr al-din Muhammad ibn Abdullah (2006), Al-Burhan fi Uloom al-Qur'an, Dar al-Hadith, Cairo.

Zarqani, Muhammad Abdul-Azim (2006), Manahil al-Irfan fi Uloom al-Qur'an, Daru Ihya al-Turath al-Arabiy, Beirut, Lebanon. 